\title{
EVALUATION OF HEAVY METALS CONCENTRATION IN SOME BOTTLED WATER BRANDS IN KURDISTAN REGION
}

\author{
Sarwar M. R. Ahmed ${ }^{\text {a }}$ \\ ${ }^{a}$ College of Engineering Agricultural Sciences, University of Duhok, Duhok, Kurdistan Region, Iraq - (sarwar.rasheed@uod.ac)
}

\begin{abstract}
:
Recently Bottled waters became the main resources for drinking water supply, where the use of bottled waters in some region has exchanged the distribution system of drinking water. However, several different chemicals may be found in drinking bottled water, for instance heavy metals, that have accumulated in lethal amounts which could affect human health after prolonged periods of exposure. Therefore, this study was carried out to evaluate some bottled water brands in Kurdistan region of Iraq in term of their contents of heavy metal comparing with both WHO and SQI water standards. About 108 samples were collected (18 brands; 6 samples from each brand) from October to December 2019, bought randomly from grocery shops and supermarkets in Duhok, Erbil and Sulaymaniyah city, Kurdistan region, Iraq. Cobalt (Co), Cadmium (Cd), Lead (Pb), Copper (Cu), Chromium (Cr), Iron $(\mathrm{Fe})$, Selenium $(\mathrm{Se})$ and Mercury $(\mathrm{Hg})$ concentrations were determined by atomic absorption spectrophotometer. Heavy metal pollution index (HPI), degree of contamination $\left(\mathrm{C}_{d e g}\right)$ and heavy metal evaluation index (HEI) were also calculated for evaluating the overall quality of bottled water. Results of individual criteria revealed that, excluding $\mathrm{Cd}$ and $\mathrm{Hg}$, heavy metals content in all bottled water samples were lower than approved limits according to Iraqi's (IQS:417) and WHO standards. Though, the results exhibited that $\mathrm{Cd}$ content in some of the studied water samples was greater than the allowable limits $(3 \mu \mathrm{g} / \mathrm{L})$ according to the depended standards. Concerning the values of metal pollution indices, although there were higher HPI values than critical value (100) in three water brands i.e. Al-Joud, Al-Waha and Sanbenedetto, the indices values for all other bottled water were below the critical value. According to the results of this study, it can be concluded that except for $\mathrm{Cd}$ value in few brands and all $\mathrm{Hg}$ values, the studied bottled water are safe for drinking. Moreover, companies of bottled water package are recommended to monitor their products through analyzing the water sample periodically and use activated carbon filtration to ensure the safety of drinking bottled water.
\end{abstract}

KEYWORDS: Bottled water, Water quality, Heavy Metals, Pollution Indices.

\section{INTRODUCTION:}

Water is one of the necessary factors for life and the primary source of intake for trace elements in the human body (Chitsazan et al., 2009). Secure drinking water could be an essential need for human health and comfort; it is a globally acknowledged as human right (WHO, 2001). Bottled waters became one of the most essential drinking water supply resources, and in some regions the use of bottled waters has replaced the drinking water distribution system (Salmani et al., 2017). The drinking-water needs for people differ based on the climate, physical movement, and culture, but for high consumers, it is appraised to be around two liters per day for a $60 \mathrm{~kg}$ person and one liter per day for a $10 \mathrm{~kg}$ child (Abd El-Salam et al., 2008). Utilization of the Bottled waters is expanding consistently around the world through the last three decades from 130,956 million liters in 2002 to 188,777 million liters in 2007 (European Federation of Bottled Water 2006; Beverage Marketing Corporation 2008). In the latest years, bottled water production had grown for over 5,000 brands around the world (Guler 2007).

In Kurdistan region, despite the presence of some secure sources of drinking water, the demand for bottled water has been increased, since the region has faced intense drought conditions (Ameen, 2019). Moreover, because of the great hazard and health concerns related with drinking of contaminated tap water, the bottled water utilization is getting prevalent all over the world, because its available at considerable cost, better taste and slight existence of contaminants (Al-Mashaikie and Ena'am, 2015). While, bottled water is possibly but not certainly safer than tap water, over the years, apprehensions have been raised about the quality of bottled water sold worldwide. Researches exhibited that the value of some components in bottled water possibly exceed the standard values for different parameters (Karamanis et al. 2007). In the physiology of human body enormous quantities of mineral compounds, particularly metal ions possess a double role, some are substantial for humans, whilst most of them are toxic at elevated contents (Karvelas et al., 2003 and Duffus, 2002). During the latest years, drinking waters quality was declined due to high pollutions increment thereby bring about serious health risks (Warburton 1993; Nkono and Asubiojo 1997; Ikem et al. 2002; Turk and Alp 2010). Toxic chemicals and metals content e.g. Mercury, Cadmium and Lead in drinking waters can give rise numerous serious diseases (Al-Saleh and Al-Doush 1998; IKem et al. 2002). Insufficient studies have been implemented on heavy metal content assessment in bottled water in Kurdistan region, so there is need for further study on this aspect to distinguish the best bottled water quality. Therefore, this study aimed to assess the heavy metal content of some bottled water brands produced and marketed in Kurdistan region and determining their validity in term of their occurrence of heavy metals with comparison to Iraqi (IQS:417, 2001) and WHO (2017) standards.

\section{MATERIALS AND METHODS}

\subsection{Sample's collection}

One hundred eight (108) samples were collected (18 brands, 6 samples from each brand) from October to December 2019, bought randomly from grocery shops and supermarkets in Duhok, Erbil and Sulaymaniyah city, Kurdistan region, Iraq. The 
container capacity was ranged from 0.33 to 0.5 liter in volume. Samples were brought to the laboratory and preserved in the fridge preceding to analysis. the bottled water information in terms of brand name, bottled water types, location and container type are presented in Table (1).

Table 1. Information of studied bottled water.

NMW = natural mineral water; $\mathbf{N S W}=$ natural spring water;

\begin{tabular}{|c|c|c|c|c|}
\hline $\begin{array}{c}\text { Numb } \\
\text { er }\end{array}$ & $\begin{array}{l}\text { Brand's } \\
\text { name }\end{array}$ & $\begin{array}{l}\text { Productio } \\
\text { n Location }\end{array}$ & $\begin{array}{l}\text { Bottle } \\
\text { d } \\
\text { water } \\
\text { types }\end{array}$ & $\begin{array}{c}\text { Types } \\
\text { of } \\
\text { Bottled } \\
\text { water } \\
\text { contain } \\
\text { er } \\
\end{array}$ \\
\hline 1 & Nestele & $\begin{array}{l}\text { Erikli - } \\
\text { Turkey }\end{array}$ & NSW & Plastic \\
\hline 2 & Al-Joud & $\begin{array}{l}\text { Duhok - } \\
\text { Iraq }\end{array}$ & NMW & Plastic \\
\hline 3 & Al-Waha & Erbil -Iraq & NMW & Plastic \\
\hline 4 & $\begin{array}{l}\text { Sanbenede } \\
\text { tto }\end{array}$ & Italy & NMW & Plastic \\
\hline 5 & Evian & $\begin{array}{c}\text { Évian-les- } \\
\text { Bains - } \\
\text { France }\end{array}$ & NMW & Plastic \\
\hline 6 & Volvic & $\begin{array}{l}\text { Auvergne } \\
\text { France- }\end{array}$ & NMW & Plastic \\
\hline 7 & Massafi & Erbil-Iraq & NMW & Plastic \\
\hline 8 & Carrefour & $\begin{array}{c}\text { Duhok - } \\
\text { Iraq }\end{array}$ & NMW & Plastic \\
\hline 9 & Life & $\begin{array}{c}\text { Zakho- } \\
\text { Duhok - } \\
\text { Iraq }\end{array}$ & NSW & Plastic \\
\hline 10 & $\begin{array}{l}\text { Hawler } \\
\text { Water }\end{array}$ & $\begin{array}{c}\text { Duhok - } \\
\text { Iraq }\end{array}$ & NMW & Plastic \\
\hline 11 & Kani & Erbil-Iraq & NSW & Plastic \\
\hline 12 & Slemani & $\begin{array}{c}\mathrm{Al} \\
\text { sulaymaniy } \\
\text { ah-Iraq }\end{array}$ & BDW & Plastic \\
\hline 13 & Shireen & $\begin{array}{l}\text { Duhok - } \\
\text { Iraq }\end{array}$ & NSW & Plastic \\
\hline 14 & Tiyan & $\begin{array}{c}\text { Zakho- } \\
\text { Duhok - } \\
\text { Iraq }\end{array}$ & NSW & Plastic \\
\hline 15 & Jiyan & $\begin{array}{c}\mathrm{Al} \\
\text { sulaymaniy } \\
\text { ah-Iraq }\end{array}$ & NMW & Plastic \\
\hline 16 & Mazi & $\begin{array}{c}\text { Duhok - } \\
\text { Iraq } \\
\end{array}$ & NSW & Plastic \\
\hline 17 & Eva & $\begin{array}{c}\text { Duhok - } \\
\text { Iraq }\end{array}$ & NSW & Plastic \\
\hline 18 & Lava & $\begin{array}{c}\text { Al } \\
\text { sulaymaniy } \\
\text { ah-Iraq }\end{array}$ & NSW & Plastic \\
\hline
\end{tabular}

BDW $=$ bottled drinking water.

\subsection{Heavy metal Metals Analysis}

Heavy metal concentrations [Cobalt (Co), Cadmium (Cd), Lead $(\mathrm{Pb})$, Copper $(\mathrm{Cu})$, Chromium $(\mathrm{Cr})$, Iron $(\mathrm{Fe})$, Selenium (Se) and Mercury $(\mathrm{Hg})]$ were determined in the water samples using GBC atomic absorption Spectrophotometer (A.A.S.) Model (932 AA) with air acetylene flame.

\subsection{Pollution Evaluation indices}

Pollution indices were specified to estimate heavy metals in bottled water samples under study. The heavy metal pollution index (HPI), degree of contamination $\left(\mathrm{C}_{\mathrm{deg}}\right)$ and heavy metal evaluation index (HEI) were used to evaluate the quality of bottled water. The mentioned indices specify an overall quality of the water with respect to heavy metals (Brraich and Jangu, 2015).

\subsubsection{Heavy metal pollution index (HPI)}

Heavy metal pollution index (HPI) of bottled water samples was evaluated by using the weighted arithmetic index method proposed by (Brown et al., 1970); HPI is an effective tool to assess the water quality with regard to heavy metals, HPI index provides the combined effect of individual heavy metal on the overall water quality (Reza and Singh, 2010).

Eight heavy metals were selected in this study for estimation of HPI. Since WHO (2017) and Iraqi standards (IQS:417, 2001) are same in studding water quality, the Iraqi standards (Maximum permissible limits) were used.

\subsubsection{HPI index calculation steps:}

1. Assigning a rating or weight $(\boldsymbol{W i})$ for each chosen heavy metals. The rating system is a randomly value from 0 to 1 and its selection based on the significance of concerns for individual quality or it can be expressed as adversely related to the proposed criteria for the corresponding parameters (Reddy, 1995; Mohan et al. 1996; Horton, 1965; Maria-Alexandra et al., 2013; Bakan et al., 2010). The unit weight (Wi) calculated by the following formula:

$$
\mathrm{Wi}=\mathrm{K} / \mathrm{Si}
$$

Where, $\mathrm{Wi}=$ unit weight for the $\mathrm{i}^{\text {th }}$ parameter (the measured heavy metal); $\mathrm{Si}=$ recommended standards value of ith parameter, $\mathrm{K}$ is the constant of proportionality, in this study its value was regarded as (1).

2. Quality rating scale (Qi) for all the parameter was computed by dividing the concentration of each parameter by its approved standard, the result then multiplied by 100 as follows:

$$
\mathbf{Q} \mathbf{i}=\left(\frac{\mathbf{C}_{\mathbf{i}}}{S_{\mathbf{i}}}\right) * \mathbf{1 0 0}
$$

Where $C_{i}$ is the heavy metal observed value of $i^{\text {th }}$ parameter, $S_{i}$ is the approved standard or allowable level for the $i^{\text {th }}$ water quality parameter. If quality rating $Q i=0$ (absolutely clean water from pollutants), While $0<Q i<100$ (contaminants are in range with proposed guidelines).

When $Q i>100$ (contaminants are higher than the criteria). Therefore, the greater the Qi value is, the more contaminated is the water. For each sample HPI was estimated by the below equation (Horton, 1965):

$$
\mathbf{H P I}=\frac{\sum \mathbf{Q}_{i} * \mathbf{W}_{\mathbf{i}}}{\sum \mathbf{W}_{\mathbf{i}}}
$$

Where Qi denoted to the quality rating of $i^{\text {th }}$ water quality parameter, $\mathbf{W i}$ is the unit weight of $\mathrm{i}^{\text {th }}$ water quality parameter. Generally, the critical pollution index of HPI value for drinking water is 100 (Prasad and Bose, 2001).

\subsection{Heavy metal evaluation index (HEI)}

As in the two previous indices (HPI and $\mathbf{C}_{\text {deg }}$ ), Heavy metal evaluation index (HEI) method is introduced to assess the total quality of water with regard to heavy metals (Backman et al., 1977), it is used to coincide the criterions for various pollution indices (Onkar and Sulochana, 2015), it can be calculated as follows: 


$$
\text { HEI }=\sum_{\mathrm{i}=\mathbf{0}}^{\mathbf{n}} \frac{\mathbf{H}_{\mathbf{0}}}{\mathbf{H}_{\mathrm{mal}}}
$$

Where, Ho is the observed value, Hmal is the maximum admissible limits (MAL) of the $\mathrm{i}^{\text {th }}$ parameter. In this study, MPL is considered as MAL depending on Iraqi standards. The classifications of $H E I$ index is proposed by Al-Ami et al $(1987)$ as follows: low $(H E I<10)$, medium $(10<H E I<20)$, and high $(H E I>20)$.

\subsection{Degree of contamination index $\left(\mathrm{C}_{d e g}\right)$}

Primarily the summation of all contamination factors called as the degree of contamination $\left(\mathrm{C}_{d e g}\right)$, it is computed in order to assess water pollution for drinking purpose. Contamination degree takes into account both the number of parameters that transcending the upper allowable level or guide values of possibly hazardous elements and the concentration exceeding these limit values (Hakanson, 1980, Al-Ami et al. 1987 and Backman et al 1997) and the $C_{d e g}$ index computed in the formula below:

$$
\begin{gathered}
\mathrm{C}_{d}=\sum_{i=1}^{n} C_{f i} \\
C_{f i}=\frac{\mathrm{C}_{A i}}{C_{N i}}-1
\end{gathered}
$$

Where: $C_{f i}=$ contamination factor for the ith component, $C_{A i}$ $=$ analytical value for the $\mathrm{i}^{\text {th }}$ component, $C_{N i}=$ upper permissible concentration of the $\mathrm{i}^{\text {th }}$ component $(\mathrm{N}$ symbolizes the normative). In this research, $C_{N i}$ is taken as Maximum permissible limits (MPL) (Table 2). The $\mathrm{C}_{\text {deg }}$ index grouping was adopted by Edet and Offiong (2002) which are: low $\left(\mathrm{C}_{d e g}\right.$ $<1)$ medium $\left(\mathrm{C}_{d e g} 1-3\right)$ and high $\left(\mathrm{C}_{d e g}>3\right)$.

\subsection{Statistical analysis}

Minitab software package (16) was used to accomplish the statistical analysis; Descriptive statistics i.e. mean and standard deviation were computed to depict the variation of each parameter. One sample T-test was applied to conclude if there were significant differences (at 95\% confidence level) in heavy metal values compared to the attributed standards.

Table 2. Recommended Standards used for indices computation of individual parameters.

\begin{tabular}{|c|c|c|}
\hline \multirow{2}{*}{ Heavy metals } & (WHO, 2017) $^{\text {Drinking water }}$ & $\begin{array}{c}\text { Iraqi standards } \\
(\text { IQS:417, 2001) }\end{array}$ \\
\cline { 2 - 3 }$(\mathbf{G V})^{\mathbf{a}}(\boldsymbol{\mu g} / \mathbf{L})$ & $\begin{array}{c}(\mathbf{M P L})^{\mathbf{b}}(\mathbf{S i}) \\
(\boldsymbol{\mu g} / \mathbf{L})\end{array}$ \\
\hline $\mathbf{C o}$ & $2000^{\mathrm{c}}$ & - \\
\hline $\mathbf{C d}$ & 3 & $3^{\mathrm{c}}$ \\
\hline $\mathbf{P b}$ & 10 & $10^{\mathrm{c}}$ \\
\hline $\mathbf{C u}$ & 2000 & $1000^{\mathrm{c}}$ \\
\hline $\mathbf{C r}$ & 50 & $50^{\mathrm{c}}$ \\
\hline $\mathbf{F e}$ & 0 & $300^{\mathrm{c}}$ \\
\hline $\mathbf{S e}$ & $10^{\mathrm{c}}$ & - \\
\hline $\mathbf{H g}$ & $1.0^{\mathrm{c}}$ & - \\
\hline
\end{tabular}

$(\mathrm{GV})^{\mathrm{a}}=$ Guideline Value; (MPL) ${ }^{\mathrm{b}}=$ Maximum Permissible Limit (IQS: 417, 2001). c =Depended Standards.

\section{RESULTS AND DISCUSSION:}

\subsection{Heavy metals concentration}

The (mean \pm standard deviation) for concentration of (8) heavy metals $(\mathrm{Co}, \mathrm{Cd}, \mathrm{Pb}, \mathrm{Cu}, \mathrm{Cr}, \mathrm{Fe}$, Se and $\mathrm{Hg})$ in 18 drinking bottled water brands are summarized in Table 3 , moreover one sample T-test analysis results and recommended standards of World Health Organization (2017) and Iraqi Standards (2001) for comparing with results were used.

The results obtained in this study clearly show that with the exception of $(\mathrm{Co})$, the content of all studied heavy metals $(\mathrm{Cd}$, $\mathrm{Pb}, \mathrm{Cu}, \mathrm{Cr}, \mathrm{Fe}, \mathrm{Se}$ and $\mathrm{Hg}$ ) were noticed in all bottled water brands collected from different locations. However, the concentrations were below the permitted standard limits which proposed by Iraqi (IQS:417, 2001) and WHO (2017) standards for drinking water, with the exception of $\mathrm{Cd}$ and $\mathrm{Hg}$.

The concentration of Cobalt in all water samples was not detected. Cadmium concentration varied from 5.83 to $1.31 \mu \mathrm{g} / \mathrm{L}$, the highest Cd value was recorded with Sanbenedetto (Figure 1), whereas the lowest value was observed in Slemani. According to One Sample T-test analysis, higher significant values of Cd (Pvalue $<0.05$ ) were noticed in Sanbenedetto, Al-Waha, Al-Joud and Nestele brands than maximum admissible concentration (3 $\mu \mathrm{g} / \mathrm{L}$ ) based on Iraqi (IQS:417, 2001) and WHO (2017) standards.

Lead concentration was between 6.86 and $0.47 \mu \mathrm{g} / \mathrm{L}$, the concentration in all brands was not significantly different, moreover its concentration was lower than the allowable limit for drinking water $(10 \mu \mathrm{g} / \mathrm{L})$. Relatively high levels of Lead were found in brands Jiyan, Volvic and Mazi with concentration levels of $4.92,3.47$ and $6.86 \mu \mathrm{g} / \mathrm{L}$, respectively. The possible $\mathrm{Pb}$ pollution sources are arising from the burning crude oil as fuel for electrical power stations, washing out water of irrigation and rainfall and fertilizers extensive uses in agricultural areas are the causes of increasing $\mathrm{Pb}$ concentration in underground water aquifers and eventually to the produced bottle waters (Abdullah and Al-Mashaikie, 2016). The different $\mathrm{Pb}$ values may be due to the various source of bottled water or water containers leakage (Salmani et al., 2017). Mahajan et al (2006), noticed that Lead content in bottled water containers can rise into the water contained in it if stored for a long time. Lead has no identified biological role for humans and is an extremely fatal metal. Its harmful health impacts comprise numerous cancers, adverse reproductive outcomes, cardiovascular and neurological syndromes (Levin et al., 1989).

With respect to the concentration of Copper in water brands, it is ranged from 6.94 to $1.31 \mu \mathrm{g} / \mathrm{l}$, although $\mathrm{Cu}$ values were not significantly different comparing to the IQS standards, the higher three values $6.94,6.17$ and $5.97 \mu \mathrm{g} / 1$ were obtained in Nestele, Al-Waha and Al-Joud brands respectively. Boateng et al (2015) remarked that $\mathrm{Cu}$ may be resulting from the natural reaction processes of water-rock since this metal was not revealed concentration values higher than Iraqi (IQS:417, 2001) and WHO (2017) limits. The obtained values of Copper in this study were correspondent with the results noticed by Miranzadeh et al (2010), in which the concentration of heavy metals across all studied samples was in congruence with the standard set by WHO and EPA. None of the bottled water samples contained Copper value above the maximum permitted level $(2000 \mu \mathrm{g} / \mathrm{l})$. However, Copper was detected in all the water samples and because Copper toxicity is related with steady low level exposure, this ultimately can lead to hazardous health impacts. Ehi-Eromosele et al., (2012) noticed that Copper leaked into drinking water from Copper pipes, its high levels in drinking water can give rise to vomiting, abdominal ache, nausea, diarrhea.

Chromium concentration in the all water brands was far below the water guideline values presented by WHO and IQS $(50 \mu \mathrm{g} / \mathrm{l})$. Iron concentrations in water were lower than the maximum 
permitted level proposed by Iraqi (IQS:417, 2001) and WHO (2017) criterions. The highest Fe value was observed with Carrefour. Fe values in all brands were ranged between 6.31 and $1.31 \mu \mathrm{g} / \mathrm{l}$, which signifies that $\mathrm{Fe}$ concentration will only influence the sensual quality for very sensitive individuals (Suffet et al. 1995). Furthermore, Lim and Lawless (2006) observed that the main tastes bitter, sweet, and sour of ferrous salts increased with increasing water $\mathrm{Fe}$ value while the metallic taste reduced.

None of the water brands transcended the Selenium permitted limit $(10 \mu \mathrm{g} / \mathrm{l})$ established by IQS and WHO standards. Jaishankar et al., (2014), indicated that Selenium and other heavy metals are necessary to conserve diverse biochemical and physiological roles in living organisms when found in very small quantity, but, they become dangerous when exceed certain threshold concentrations.

Mercury consider as one of the detrimental heavy metals for human body, its value ranged between 3.53- $1.39 \mu \mathrm{g} / \mathrm{L}$ (Figure 2), the $\mathrm{Hg}$ concentration in all brands was significantly higher $(\mathrm{P}$-value $<0.05)$ than the maximum allowable limit $(1.0 \mu \mathrm{g} / \mathrm{l})$ recommended by IQS and WHO standards. Higher values $(3.53,3.44,3.22$ and $3.14 \mu \mathrm{g} / \mathrm{l})$ were revealed in Shireen, Sanbenedetto, Massafi and Kani, respectively.

\subsection{Pollution Assessment indices}

In general, pollution indices are applied for water pollution evaluation in study samples (brraich and jangu, 2015). The current methodology presumes that the concurrent use of several indices has been found for further precisely evaluation for heavy metal pollution (Kowalska et al. 2018). In this study, calculation of pollution indices depended on (SQI and WHO) standards Table (2), and the mean of these selected heavy metal values $(\mathrm{Co}, \mathrm{Cd}, \mathrm{Pb}, \mathrm{Cu}, \mathrm{Cr}, \mathrm{Fe}, \mathrm{Se}$ and $\mathrm{Hg})$.

The heavy metal pollution index (HPI), contamination degree $\left(\mathrm{C}_{d e g}\right)$ and heavy metal evaluation index (HEI) values of bottled water brands were computed depending on WHO (2017) and Iraqi Standards (IQS:417, 2001) (Table 4), HPI values for bottled water samples were varied from 126.8633.13, all water brands were below the critical pollution index limit of HPI (100) (Table 4 \& 5), except for the AlJoud, Al-Waha and Sanbenedetto brands (103.34, 110.92 and 126.86) respectively , their values were more than the critical threshold pollution index value, while Nestle (98.77), Jiyan (80.33) and Volvic (88.19) were close to the critical value, accumulation of heavy metal may reach the critical pollution value if the effective measures are not taken for minimizing heavy metal content in water. The high HPI values in the above-mentioned brands may be due to the high $\mathrm{Cd}$ and $\mathrm{Pb}$ values, which in turn caused the increment in unit weight (Wi) of $\mathrm{Cd}$ and $\mathrm{Pb}$ compared to the rest heavy metals $(\mathrm{Co}, \mathrm{Cu}, \mathrm{Cr}, \mathrm{Fe}, \mathrm{Se}$ and $\mathrm{Hg}$ ).

The results in table (4) showed that the degree of contamination $\left(\mathrm{C}_{\text {deg }}\right)$ for all bottled water samples had the negative values, the highest value was recorded in Volvic brand (-4.35), and the lowest value was noticed in Eva brand -6.13. the negative values indicating safety use of water for drinking, it appeared that all water sampled were laid in class 1 that categorized by low contamination $\left(\mathrm{C}_{\text {deg }}<1\right)$ (Edet and Offiong 2002) (Table 5). Similar results were found by Abdelhady El-Hady et al., (2017). The calculated average values of heavy metal evaluation index (HEI) ranged from 0.87 - 2.65 (Table 4). According to the HEI criteria proposed by Al-Ami et al (1987), the studied water brands were belonging to the low level of heavy metals (HEI < $10)$.

Table 4. Heavy metal pollution indices.

\begin{tabular}{|c|c|c|c|}
\hline \multirow{2}{*}{ Brand Name } & \multicolumn{3}{|c|}{ Indices } \\
\cline { 2 - 4 } & HPI & $\mathbf{C}_{\text {deg }}$ & HEI \\
\hline Nestele & 98.77 & -4.72 & 2.28 \\
\hline Al-Joud & 103.34 & -4.79 & 2.21 \\
\hline Al-Waha & 110.92 & -4.52 & 2.48 \\
\hline Sanbenedetto & 126.86 & -4.39 & 2.61 \\
\hline Evian & 52.66 & -5.17 & 1.83 \\
\hline Volvic & 88.19 & -4.35 & 2.65 \\
\hline Massafi & 47.93 & -5.41 & 1.59 \\
\hline Carrefour & 57.08 & -5.62 & 1.38 \\
\hline Life & 75.96 & -5.23 & 1.77 \\
\hline Hawler & 71.85 & -5.28 & 1.72 \\
\hline Water & 62.61 & -5.55 & 1.45 \\
\hline Kani & 33.13 & -5.93 & 1.07 \\
\hline Slemani & 48.85 & -5.76 & 1.24 \\
\hline Shireen & 45.07 & -5.68 & 1.32 \\
\hline Tiyan & 80.33 & -5.19 & 1.81 \\
\hline Jiyan & 48.49 & -5.59 & 1.41 \\
\hline Mazi & 34.85 & -6.13 & 0.87 \\
\hline Eva & 45.07 & -5.70 & 1.30 \\
\hline Lava
\end{tabular}

HPI= Heavy Metal Pollution Index

$\mathrm{C}_{\text {deg }}=$ Contamination Degree,

HEI= Heavy Metal Environmental Index. 
Table 3. Comparison of measured heavy metal concentrations of studied bottles water with their standards (IQS and WHO)

\begin{tabular}{|c|c|c|c|c|c|c|c|c|}
\hline Brand name & Co & $\mathbf{C d}$ & $\mathbf{P b}$ & $\mathbf{C u}$ & $\mathrm{Cr}$ & $\mathbf{F e}$ & Se & $\mathbf{H g}$ \\
\hline & \multicolumn{8}{|c|}{$\mu \mathrm{g} / \mathrm{L}$} \\
\hline Standards & $2000^{c}$ & $3^{d}$ & $10^{\mathrm{d}}$ & $2000^{d}$ & $\mathbf{5 0}^{\mathrm{d}}$ & $300^{d}$ & $10^{c}$ & $1.0^{\mathrm{c}}$ \\
\hline Nestele & 0 & $4.31 * \pm 0.40$ & $1.36 \pm 1.15$ & $6.94 \pm 3.39$ & $6.53 \pm 4.69$ & $3.47 \pm 1.42$ & $5.61 \pm 0.80$ & $2.53 * \pm 1.42$ \\
\hline Al-Joud & 0 & $4.78 * \pm 0.75$ & $0.47 \pm 0.45$ & $5.97 \pm 4.33$ & $9.31 \pm 3.89$ & $2.86 \pm 1.36$ & $3.69 \pm 1.08$ & $1.92 * \pm 0.67$ \\
\hline Al-Waha & 0 & $5.00 * \pm 0.71$ & $1.19 \pm 0.83$ & $6.17 \pm 1.33$ & $10.89 \pm 3.82$ & $1.31 \pm 0.40$ & $4.67 \pm 2.36$ & $2.53 * \pm 1.42$ \\
\hline Sanbenedetto & 0 & $5.83 * \pm 1.81$ & $1.47 \pm 0.45$ & $3.75 \pm 1.73$ & $3.83 \pm 2.40$ & $1.31 \pm 0.40$ & $4.31 \pm 0.40$ & $3.44 * \pm 1.66$ \\
\hline Evian & 0 & $1.78 \pm 0.75$ & $2.64 \pm 1.71$ & $3.39 \pm 1.46$ & $16.61 \pm 7.96$ & $2.17 \pm 1.13$ & $6.31 \pm 1.78$ & $1.69 * \pm 0.40$ \\
\hline Volvic & 0 & $3.69 \pm 1.08$ & $3.47 \pm 1.42$ & $3.14 \pm 1.36$ & $37.31 \pm 7.43$ & $2.92 \pm 1.20$ & $3.17 \pm 1.33$ & $1.39 * \pm 0.38$ \\
\hline Massafi & 0 & $1.92 \pm 0.67$ & $1.31 \pm 0.40$ & $2.78 \pm 1.03$ & $24.50 \pm 10.35$ & $3.08 \pm 1.20$ & $3.14 \pm 1.36$ & $3.22 * \pm 1.03$ \\
\hline Carrefour & 0 & $2.53 \pm 1.42$ & $1.69 \pm 0.40$ & $1.31 \pm 0.40$ & $8.69 \pm 2.48$ & $6.31 \pm 1.78$ & $1.69 \pm 0.40$ & $2.92 * \pm 1.86$ \\
\hline Life & 0 & $3.39 \pm 1.46$ & $1.31 \pm 0.40$ & $2.17 \pm 1.13$ & $9.92 \pm 3.23$ & $3.17 \pm 1.33$ & $3.00 \pm 1.41$ & $2.47 * \pm 1.00$ \\
\hline Hawler Water & 0 & $3.14 \pm 1.36$ & $1.92 \pm 1.20$ & $1.69 \pm 0.40$ & $8.83 \pm 3.71$ & $3.14 \pm 1.36$ & $2.92 \pm 1.86$ & $1.61 * \pm 0.38$ \\
\hline Kani & 0 & $2.78 \pm 1.03$ & $1.31 \pm 0.40$ & $4.36 \pm 3.79$ & $6.70 \pm 1.78$ & $2.31 \pm 0.40$ & $2.47 \pm 1.00$ & $3.14 * \pm 1.69$ \\
\hline Slemani & 0 & $1.31 \pm 0.40$ & $1.69 \pm 0.40$ & $1.31 \pm 0.40$ & $14.33 \pm 3.61$ & $2.86 \pm 1.36$ & $1.69 \pm 0.40$ & $2.47 * \pm 1.00$ \\
\hline Shireen & 0 & $2.17 \pm 1.13$ & $0.78 \pm 0.75$ & $3.00 \pm 1.41$ & $11.56 \pm 3.84$ & $4.17 \pm 1.33$ & $1.92 \pm 0.67$ & $3.53 * \pm 1.42$ \\
\hline Tiyan & 0 & $1.69 \pm 0.40$ & $1.83 \pm 1.33$ & $2.92 \pm 1.86$ & $7.69 \pm 6.95$ & $1.31 \pm 0.40$ & $4.17 \pm 1.33$ & $2.47 * \pm 1.00$ \\
\hline Jiyan & 0 & $3.44 \pm 1.66$ & $4.92 \pm 3.23$ & $2.47 \pm 1.00$ & $0.00 \pm 0.00$ & $2.00 \pm 0.71$ & $1.61 \pm 0.38$ & $1.61 * \pm 0.38$ \\
\hline Mazi & 0 & $1.69 \pm 0.40$ & $6.86 \pm 1.69$ & $1.69 \pm 0.40$ & $1.22 \pm 1.03$ & $2.31 \pm 1.08$ & $1.31 \pm 0.40$ & $2.22 \pm 1.60$ \\
\hline Eva & 0 & $1.39 \pm 0.38$ & $2.61 \pm 0.80$ & $1.92 \pm 0.67$ & $0.00 \pm 0.00$ & $1.31 \pm 0.40$ & $1.39 \pm 0.38$ & $2.92 * \pm 1.86$ \\
\hline Lava & 0 & $1.69 \pm 0.40$ & $2.53 \pm 1.42$ & $3.17 \pm 1.13$ & $6.42 \pm 8.40$ & $1.31 \pm 0.40$ & $3.53 \pm 1.42$ & $2.47^{*} \pm 1.00$ \\
\hline
\end{tabular}

$*$ = measured value significantly greater than recommended standard value. $\mathrm{c}=($ WHO, 2017): Drinking water, (Guideline value) .

$\mathrm{d}=$ Iraqi standards (IQS: 417, 2001), (Maximum admissible concentration). $\pm=$ standard deviation.

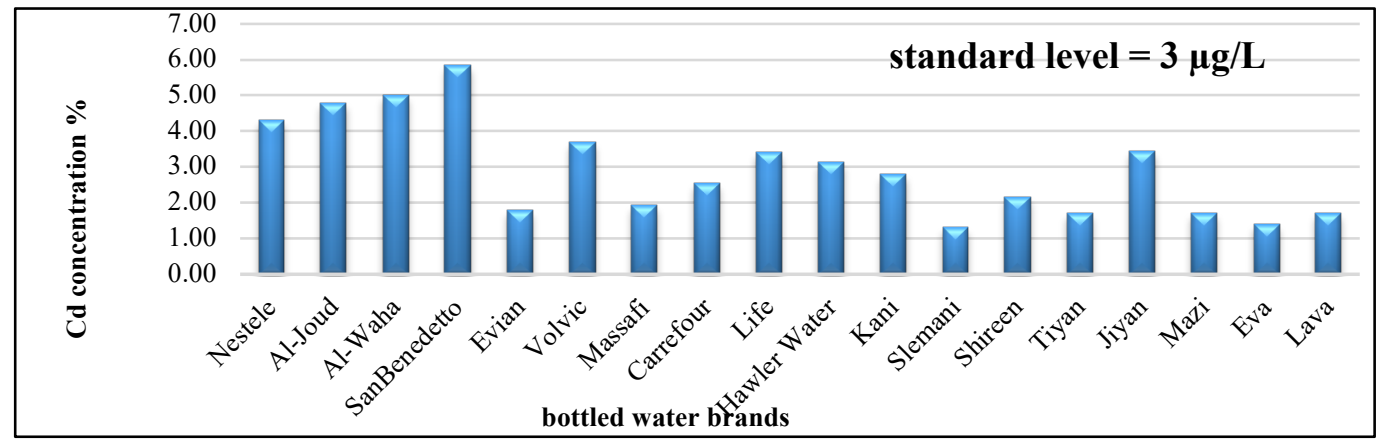

Figure 1. Concentration of Cadmium in bottled water brands

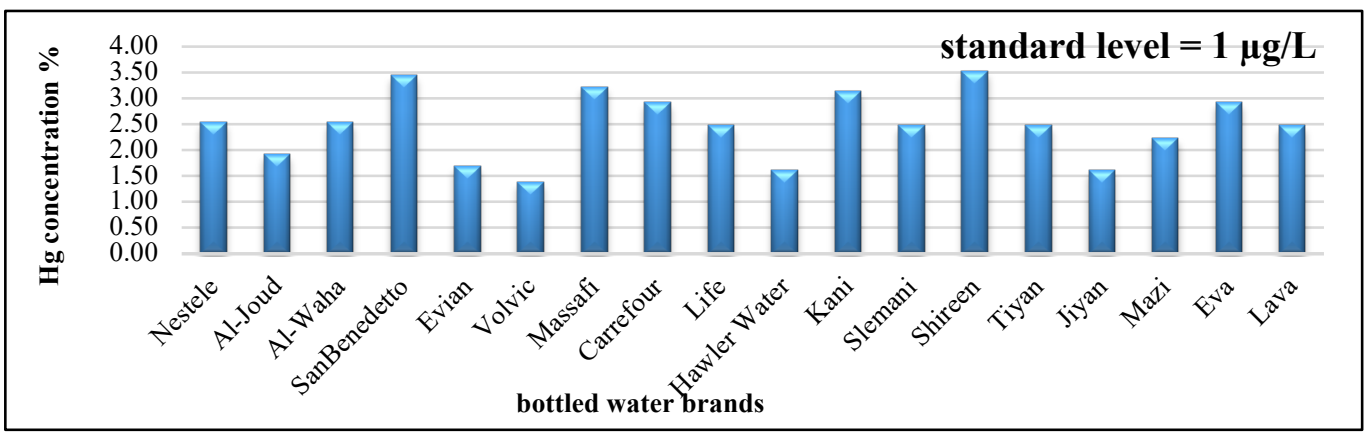

Figure 2. Concentration of Mercury in bottled water brands 
Table 5. Categories of Heavy metal pollution indices

\begin{tabular}{|c|c|c|c|}
\hline Index & Category & $\begin{array}{c}\text { Contamination } \\
\text { degree }\end{array}$ & References \\
\hline \multirow[t]{3}{*}{ HPI } & $<100$ & Low & \multirow{3}{*}{$\begin{array}{c}\text { Horton, } \\
\text { (1965) }\end{array}$} \\
\hline & $=100$ & Threshold risk & \\
\hline & $>100$ & High & \\
\hline \multirow[t]{3}{*}{ HEI } & $<10$ & Low & \multirow{3}{*}{$\begin{array}{l}\text { Al-Ami et } \\
\text { al. (1987) }\end{array}$} \\
\hline & $10-20$ & Medium & \\
\hline & $>20$ & High & \\
\hline \multirow[t]{3}{*}{$\mathbf{C}_{d e g}$} & $<1$ & Low & \multirow{3}{*}{$\begin{array}{c}\text { Edet and } \\
\text { Offiong, } \\
\text { (2002) }\end{array}$} \\
\hline & $1-3$ & Medium & \\
\hline & $>3$ & High & \\
\hline
\end{tabular}

\section{CONCLUSION}

Pollution evaluation indices were used to evaluate the contamination of water quality by heavy metal and its safety for drinking usage. With the exception of $\mathrm{Cd}$ and $\mathrm{Hg}$, the concentration of all heavy metal in the studied bottled water brands was lower than the allowable limit proposed by WHO (2017) and Iraqi Standards (IQS:417, 2001), the ingestion of water, containing elevated levels of $\mathrm{Cd}$ and $\mathrm{Hg}$ may cause significant health risks. It was appeared that the calculated pollution indices of all bottled water samples were less than the standard contamination level, excluding HPI value in some water brands which was marginally above the critical threshold limit. In the current study, based on the computed pollution indices (HPI, $\mathrm{C}_{d e g}$ and $\mathrm{HEI}$ ), the studied water samples are safe for drinking and make no health hazard to the people in respect to heavy metal content, however continuous usage of bottled water contain heavy metal even in low content, can cause serious health risk, including damage to the nervous system, kidneys, since the constant use of heavy metal contained water for drinking may cause the accumulation of heavy metal content and exceed the permissible standard limit, therefore it is recommended for companies of bottled water package to monitor the water through analyzing annually or once every two years to ensure that the heavy metal content are lower than admissible level.

\section{ACKNOWLEDGMENTS:}

I appreciate the research center at the College of Engineering Agricultural Sciences, University of Duhok for permitting me to access the laboratory equipment. Sincere appreciation is also extended to College of Engineering Agricultural Sciences, University of Duhok, for assisting in financial and practical support to apply this research.

\section{REFERENCES:}

Abd El-Salam, M. M. M., El-Ghitany, E. M. A. and Kassem, M. M. M. (2008). Quality of Bottled Water Brands in Egypt Part I: Physico-Chemical Analyses. J. of Egypt Public Health Assoc. (83) 5 \& 6.: 370-388.

Abdelhady El-Hady, A. M., E. F. Abdelaty and A. E. Boder. (2017). Assessment of Heavy Metals Pollution of Some Water Resources (Kafr El-Dawar-Egypt), Natural Resources, 8: 306-319.

Abdullah E. J., S. Z. A. K. Al-Mashaikie. (2016). Geochemical Impacts of the Physical Parameters and Heavy Metals Risk of the Drinking Bottled Water Produced and Marketed in Baghdad City, Iraq, Journal of Natural Sciences Research, $6(14)$.
Al-Mashaikie, S. Z. A. K. and Ena'am J. A. (2015). Quality assessment of physico-chemical parameters for various bottled waters marketed in Baghdad City, Iraq; An environmental approach. Journal of Environment and Earth Science, 5(2): 125-136.

Al-Saleh, I. and Al-Doush, I. (1998). "Survey of trace elements in household and bottled drinking water samples collected in Riyadh, Saudi Arabia". The Science of the Total Environment, 216:181-192.

Ameen, H. A. (2019). Physicochemical quality evaluation of some brands of bottled water in Kurdistan region, Iraq: comparison of analytical results with labels and standards. Journal of university of Duhok., (22) 1, (agri. And vet. Sciences): 221-233.

Backman, B.; Bodis D, Lahermo, P.; Rapant, S.; Tarvainen, T. (1977). Application of a groundwater contamination index in Finland and Slovakia. Environ. Geology., 36: 55-64.

Bakan, G.; Özkoç, H.B.; Tülek, S.; Cüce, H. (2010). Integrated environmental quality assessment of the Kizilırmak River and its coastal environment. Turk. J. Fish. Aquat. Sci., 10: 453-462.

Beverage Marketing Corporation (BMC), (2008). Market report findings. BMC, from http://www.beverage marketing.co.

Boateng TK:Opoku F,Acquaah S. O., Akoto, O. (2015). Pollution evaluation, sources and risk assessment of heavy metals in handdug wells from Ejisu-Juaben Municipality, Ghana. Environ. Syst. Res. 4(1): 18. https://doi.org/ 10.11 86/s40068-O 15-0045y.

Brown R.M. McClelland N.I. Deininger R.A. and Tozer R.G., (1970). A Water Quality Index- Do We Dare, https://doi.org/10.1007/s13201- 016-0451.

Brraich O.S. and Jangu S., (2015). Evaluation of water quality pollution indices for heavy metal contamination monitoring in the water of Harike Wetland (Ramsar Site), India. International Journal of Scientific and Research Publications, 5(2): 1-6.

Chitsazan M, Dorraninejad M, Zarasvandi A, et al. (2009). Occurrence, distribution and source of heavy metals in deep groundwater wells in Maydavood area, southwestern Iran. Environ Geol. 58(4): 727-37.

Drinking-Water Standard, (IQS:417), (2001). Central Organization for Quality Control and Standardization, Council of Ministers, Republic of Iraq.

Duffus J. H. (2002). Heavy metals, a meaningless term? (IUPAC Technical Report). Pure and Applied Chemistry, 74(5): 793-807.

Edet A. E., Offiong O. E. (2002). Evaluation of water quality pollution indices for heavy metal contamination monitoring. A study case from Akpabuyo-Odukpani area, Lower Cross River Basin (southeastern Nigeria). Geo J. 57:295- 304.

Ehi-Eromosele C. O., Okiei, W. O. (2012). Resources and Environment, 2(3): 82-86 DOI :10.5923/j.re.20120203.01

European Federation of Bottled Water (EFBW), (2006). The bottled water industry in figures. Brussels, Belgium: EFBW. http://www.efbw.org/about/industry.

Guler, C. (2007). Evaluation of maximum contaminant levels in Turkish bottled drinking waters utilizing parameters reported on manufacturer's labeling and government-issued production licenses. Journal of Food Composition Analysis, 20, 262-272.

Hakanson, L. (1980). An ecological risk index for aquatic. Pollution control: A sedimentological approach. Water Research, 14: 975-1001.

Horton, R. K. (1965). An index system for rating water quality. J. Water Pollut. Control Fed. 37(3):300-306.

Ikem, A. Odueyungbo, S. Egiebro, NO. and Nyavor, K. (2002). Chemical quality of bottled waters from three cities in eastern Alabama. Sci. Total Environ., 285: 165-175.

Jaishankar M, Tseten T, Anbalagan N, et al. Toxicity, mechanism and health effects of some heavy metals. Interdiscip Toxicol. 2014; 7(2): 60-72.

Karamanis D, Stamoulis K, Ioannides KG. (2007). Natural radionuclides and heavy metals in bottled water in Greece. Desalination, 213, 90-97.

Karvelas M, Katsoyiannis A, Samara C. Occurrence and fate of heavy metals in the wastewater treatment process. Chemosphere. 2003; 53(10): 1201-10.

Kowalska, J. B., Ryszard M., M. G. Siorek. Pollution indices as useful tools for the comprehensive evaluation of the degree of soil contamination-A review, Environ Geochem Health (2018) 40:2395-2420, https://doi.org/10.1007/s10653-018-0106-z.

Levin, R.; Schock, M.R.; Marcus, A.H. Exposure to Lead in U. S. drinking water. In Proceedings of the $23 \mathrm{rd}$ Annual Conference on Trace Substances in Environmental Health, US Environmental Protection Agency, Cincinnati, OH, 1989. 
Lim J, Lawless HT. 2006. Detection thresholds and taste qualities of iron salts. Food Qual Pref 17:513-21.

M. Y. Al-Ami, S. M. Al-Nakib, N. M. Ritha, A. M. Nouri, A. AlAssina, Water quality index applied to the classification and zoning of Al-Jayshcanal, Bagdad, Iraq, J Environ. Sci. Health A. 22 (1987) 305-319.

Maria-Alexandra H, Roman C, Ristoiu D, Popita G, Tanaselia C. Assessing of water quality pollution Indices for heavy metal contamination. A study case from Medias City groundwaters. Agric Sci Pract; 3-4: 25-31. (2013).

Miranzadeh MB, Hassani AH, Iranshahi L, Ehsanifar M., Heidari M. Study of microbial quality and heavy metal determination in 15 brands of Iranian bottled drinking water during 20092010. Journal of Ardabil University of Medical Sciences. 2011; (1): 44-8.

Mohan, S.V., Nithila, P., Reddy, S.J. (1996): Estimation of heavy metal in drinking water and development of heavy metal pollution index. - Journal of Environmental Science and Health 31: 283-289.

Nkono, NA. and Asubiojo, OI. (1997). Trace elements in bottled and soft drinks in Nigeria-a preliminary study. The Science of the Total Environment 208: 161-163.

Onkar, S. B., Sulochana, J. (2015). Evaluation of Water Quality Pollution Indices for Heavy Metal Contamination Monitoring in the Water of Harike Wetland (Ramsar Site), India. Int. J. Sci. and Research Publications, 5: 1-6.
Prasad B. and Bose, J., (2001). Evaluation of the heavy metal pollution index for surface and spring water near a limestone mining area of the lower Himalayas. Environmental Geology, 41(1-2): 183188. https://doi.org/10.1007/s002540100380.

Reddy, S. J. (1995): Encyclopedia of environmental pollution and control. - Environmental media, Karela, India.

Reza, R., Singh, G. (2010). Heavy metal contamination and its indexing approach for river water. Int. J. Environ. Sci. Technol. 7: 785792. https:// doi.org /10.1007 /BF03326187.

Salmani MH, Talebi P, Ebrahimpoor O. (2017). Investigating the Concentration of Heavy Metals in Bottled Water and Comparing with its Standard: Case Study. J Environ Health Sustain Dev., 2(3): 340-7.

Suffet I. H., Mallevialle J., Kawczynski E. (1995). Advances in taste-andodor treatment and control. Denver: American Water Works Assn. Research Foundation. p 385.

Turk, T. and Alp, I. (2010). Adsorption of as (III) from Water Using MgFe-Hydrotalcite (FeHT). Ekoloji 19 (74):77-88.

Warburton, DWA. (1993). Review of the microbiological quality of bottled water sold in Canada. Part 2. The need for more stringent standards and regulations. Can. J. Microbiol., 39:158-168.

WHO, (2001). Water health and human rights, World Water Day. Available online at http://www.worldwaterday.org/themtic/ hmnrights. html.n4.

WHO, (2007). Chemical safety of drinking water: assessing priorities for risk management. World Health Organization, Geneva, Switzerland. 